\title{
ПЕТРОГРАФИЧЕСКИЕ И МИНЕРАЛОГИЧЕСКИЕ ПРИЗНАКИ ВЗАИМОДЕЙСТВИЯ ГРАНИТОИДНЫХ И ГАББРОИДНЫХ МАГМ ПЛУТОНА ПОТУДАНЬ, ВОРОНЕЖСКИЙ КРИСТАЛЛИЧЕСКИЙ МАССИВ
}

\author{
М. Е. Петракова, Р. А. Терентьев \\ Воронежский государственный университет
}

Поступила в редакцию 30 ноября 2017 г.

\begin{abstract}
Аннотация: в Донском поясе Воронежского кристаллического массива, в поле развития Хохольско-Репьевского батолита павловского гранитоидного комплекса выявлен плутон Потудань. Впервые представлены детальные петрографические, минералогические и геохимические данные по породам плутона и сравнение с окружающими магматическими комплексами региона. Несколько разобщенных штоков плутона общей площадью 15 км сложены массивными, равномернозернистыми темными породами, дифференцированными от кварцевых монцогаббро до гранодиоритов. Спорадически встречаются порфировидные директивные разновидности с признаками гибридизма габброидов и вмещающих гранитоидов. Породы плутона Потудань являются железистыми, метаглиноземистыми, высококалиевыми и имеют широкий диапазон по $\mathrm{SiO}_{2}$ от 49, 1 до 63,9 мас. \%, демонстрируя контрастные отличия от известных региональных комплексов. Условия кристаллизаџии плутона Потудань: давления 2,7-3,2 кбар; температуры от 1047-1154 ${ }^{\circ} \mathrm{C}$ до 713-851 ${ }^{\circ}$. Полученные параметры (высокие стартовые температуры и литостатическое давление) сопоставимы с таковыми по гранитоидам павловского комплекса. Минералогопетрографические особенности пород плутона Потудань, такие как прямая и реверсивная зональность плагиоклаза с резким изменением состава от ядра к краю, ситовидный плагиоклаз, квариевые и/или калишпатовые ойкокристалль, игольчатый апатит и другие признаки гибридизма габброидов плутона и вмещзающих гранитоидов свидетельствуют о смешении в разных пропорииях мафитовой и кислой магм в верхнекоровых условиях.
\end{abstract}

Ключевые слова: Восточно-Сарматский ороген, палеопротерозой, железистые габброграниты, условия кристаллизации, смешение магм

\section{PETROGRAPHIC AND MINERALOGICAL EVIDENCE OF FELSIC AND MAFIC MAGMAS INTERACTION IN THE POTUDAN PLUTON, VORONEZH CRYSTALLINE MASSIF}

\begin{abstract}
Potudan pluton was discovered within the Khokhol-Repyevka batholith of Pavlovsk granithoid complex in the Don belt of Voronezh crystalline massif. Here we present a first detailed petrographic, mineralogical and geochemical study of the Potudan rock suite and comparison with the other coeval magmatic rocks in the region. Separate stocks of the pluton with a total area of $15 \mathrm{~km}^{2}$ are composed mainly of massive equigranular dark rocks differentiated from quartz monzogabbro to granodiorites. Porphyritic foliation rock varieties with hybridism signatures of the mafic rocks and host granitoid are sporadically observed. The Potudan pluton rocks are ferroan, metaluminous, high-K calc-alkaline and span a wide range in $\mathrm{SiO}_{2}$ contents from 49,1 to 63,9 wt.\%, showing a distinct composition from the regional complexes. The crystallization condition of the Potudan pluton are $P=2,7-3,2 \mathrm{kbar}, \mathrm{T}\left({ }^{\circ} \mathrm{C}\right)$ from 1047-1154 ${ }^{\circ} \mathrm{C}$ to $713-851{ }^{\circ} \mathrm{C}$. The obtained parameters (high initial temperatures and pressure) are comparable with the PT-conditions of Pavlovsk complex granitoids. Mineralogical and petrographic features of the Potudan pluton, such as the normally and reversely zoned plagioclase with a sharp change in composition from the crystal core to rim, sieved plagioclase, quartz and/or feldspar oikocrysts, acicular apatite, together with the indications of gabbroid and host granitoid hybridism suggest that the mafic and felsic magmas were mixed in different proportions within the upper crustal conditions.
\end{abstract}

Keywords: East Sarmatian orogen, Paleoproterozoic, ferroan gabbro-granite suite, crystallization condition, magma mixing. 


\section{Введение}

Один из террейнов зоны сочленения Сарматского и Волго-Уральского сегментов [1] Восточно-Европейского кратона (рис. 1а), в юго-восточной части Воронежского кристаллического массива (ВКМ) состоит из: (1) гнейсов основания и известковосиликатных пород с прослоями амфиболитов (донская серия), (2) батолитов палеопротерозойских калиевых гранитоидов павловского комплекса, простирающихся с севера на юг и (3) небольших мафитовых интрузий горнблендитов, мелагаббро/габброамфиболитов предположительно архейского возраста (белогорьевский комплекс, [2]). В южной части Донского террейна расположен наиболее изученный Павловский батолит, являющийся типовым представителем гранитоидного комплекса. Недавно был продемонстрирован высокомагнезиальный характер магм Павловского плутона [3]. Батолит сопоставлялся [3] с гранитоидами Клосепет-типа и архейскими санукитоидами мантийного происхождения $[4,5]$. Однако ранее, плавление коровых метавулканогенно-осадочных толщ донской серии было доминирующей точкой зрения на генезис гранитоидов павловского комплекса [6, 7].

В северной части Донского террейна расположен слабо изученный Хохольско-Репьевский батолит (рис. $16)$, сложенный породами, отвечающими по составу гранитоидам павловского типа. В южной части батолита по геофизическим данным (контрастные положительные аномалии гравитационного поля) выявлен массив меланократовых пород (плутон Потудань, рис. 16 , врезка). Сведения о вещественном составе плутона Потудань очень скудны и хранятся исключительно в фондах Белогородской области. На карте докембрия ВКМ масштаба 1:500 000 [8] он был включен в состав белогорьевского горнблендит-габбрового комплекса. Тем не менее, характерные особенности плутона, такие как присутствие кварца, калиевого полевого шпата, средний химизм некоторых образцов и микроструктурные особенности сближают его с наиболее меланократовыми породами павловского комплекса. $\mathrm{C}$ другой стороны, обилие пироксена и равномерная зернистость пород плутона контрастно отличают их от порфировидных, беспироксеновых павловских гранитоидов.

Вследствие указанных выше противоречий, целями статьи являются: 1) представить детальные петрографические, минералогические и химические данные по породам плутона Потудань; 2) провести сравнение плутона Потудань со смежными магматическими комплексами, установить характер связи с павловскими гранитоидами; 3) оценить условия кристаллизации и внедрения магм.

\section{Геологическая позиция}

Плутон Потудань находится в районе с. Солдатское в 25 км к северу от города Острогожска и в 86 км к югу от города Воронежа, на левом и правом берегах реки Потудань. Геологически расположен в пределах центральной части Донского пояса Восточно-Сарматского орогена (ВСО), разделяющего Сарматский и ВолгоУральский архейские сегменты земной коры [1]. Центральная и восточная части ВКМ развивались как ороген, который сформировался в палеопротерозое за счет столкновения Сарматского и Волго-Уральского сегментов Восточно-Европейской платформы [1] (рис. 1а).

В пределах Донского и сопряженного с ним Лосевского поясов выделяются несколько гранитоидных комплексов. Среди пород лосевской серии развит усманский тоналит-трондьемит-гранодиоритовый и ряд других гранитоидных комплексов. В поле развития амфиболит-гнейсовых пород донской серии традиционно выделяются павловский гранитоидный и белогорьевский горнблендит-габбровый комплексы. Изучаемый плутон находится в окружении гранитоидов Хохольско-Репьевского батолита павловского комплекса. (рис. 1б). Плутон Потудань представляет собой серию разобщенных штоков общей площадью около 15 км$^{2}$ (рис. 1б, врезка), он вскрыт более чем 10 скважинами с максимальной глубиной 405 м. В центральной части штоки плутона сложены равномернозернистыми, массивными мафитовыми породами, содержащими клинопироксен. К краевой части зернистость пород увеличивается, исчезает клинопироксен, породы сменяются порфировидными роговообманково-биотитовыми гранитоидами, аналогичными породам павловского комплекса. В некоторых скважинах наблюдаются участки гибридных директивных пород, несущих структурные и вещественные признаки обоих: и мафитов плутона Потудань, и гранитоидов павловского типа. К завершающей фазе магматической активности в пределах Хохольско-Репьевского батолита относятся дайки мелкозернистых розовых лейкогранитов мощностью от нескольких сантиметров до первых метров, имеющих секущие взаимоотношения со всеми остальными геологическими подразделениями.

\section{Фактический материал и методы исследования}

В работе использованы образцы керна скважин, из которых были изготовлены прозрачно-полированные шлифы. Петрографическое описание горных пород, взаимоотношения минералов, их кристаллооптические свойства изучались при помощи прямого оптического поляризационного микроскопа OLYMPUS BX51-P. Количественно-минеральный подсчет в шлифах осуществлен линейным методом на интеграционном столике конструкции Андина. Объектив $10^{\mathrm{x}}$, количество линий от 7 до 10, расстояние между линиями 0,1 мм. Для наименования пород применена QAP модальная диаграмма Штрекайзена [9].

Микрозондовые исследования проводились на растровом электронном микроскопе Jeol 6380 LV c энергодисперсионным анализатором INCA 250 (ВГУ, аналитик Н.С. Базиков). Условия анализа: ускоряющее напряжение 20 кВ, ток зонда 1,2 mA, время набоpa спектра 70 сек, диаметр пучка 1-3 мкм. ZAF коррекция при расчете содержания окислов и оценка точности проводились с помощью комплекта программ математического обеспечения системы. 

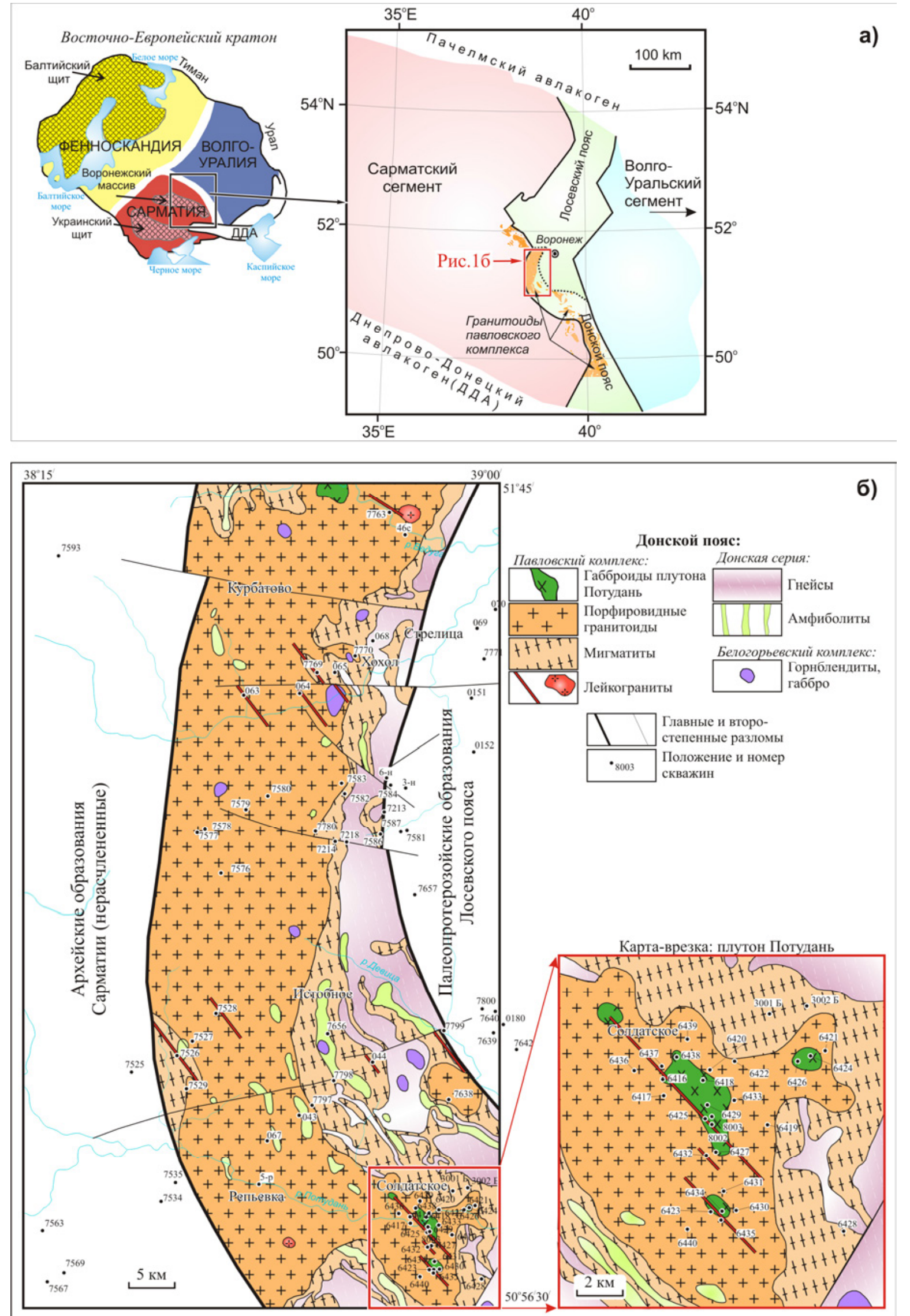

Puc. 1. $a$ - Схема расположения ВКМ в пределах Восточно-Европейского кратона, $\sigma$ - Геологическая схема ХохольскоРепьевского батолита, на врезке - плутон Потудань. 
Образцы пород для силикатного анализа были истерты в порошок с крупностью зерен 50 мкм. Затем методом квартования отобрана навеска массой 1г. Далее образцы были высушены при температуре $110^{\circ}$ С до состояния воздушно-сухой пробы, затем - прокалены до постоянной массы при температуре $1000^{\circ}$ С. Подготовка излучателей для анализа породообразующих элементов выполнена путем плавления 0,5 г порошка пробы, 2 г тетрабората лития и 2 г метабората лития в муфельной печи с последующим отливом стеклообразного диска. Химический состав проб определен на рентгенофлуоресцентном спектрометре S8 Tiger (Bruker AXS GmbH, Германия). Результаты исследований получены на оборудовании ЦКПНО ВГУ (аналитик Е.Х. Кориш). При калибровке спектрометра и для контроля качества измерений были использованы государственные стандартные образцы химического состава горных пород - ГСО №88712007, ГСО № 3333-85, ГСО № 3191-85. Точность анализа составляла $1-2 \%$ отн. \% для элементов с концентрациями выше 1-5 мас. \% и до 5 отн. \% для элементов с концентрацией ниже 0,5 мас. \%.

\section{Результаты исследования Петрография и минералогия}

Базируясь на количественно-минеральной классификации [9] и текстурно-структурных особенностях изученные образцы разделены на три типа: (1) кварцевые монцогаббро-диориты Потуданского типа; (2) гранитоиды павловского комплекса и (3) гибридные породы.

Квариевые монияогаббро-диориты плутона Потудань.

Эти меланократовые породы характеризуются

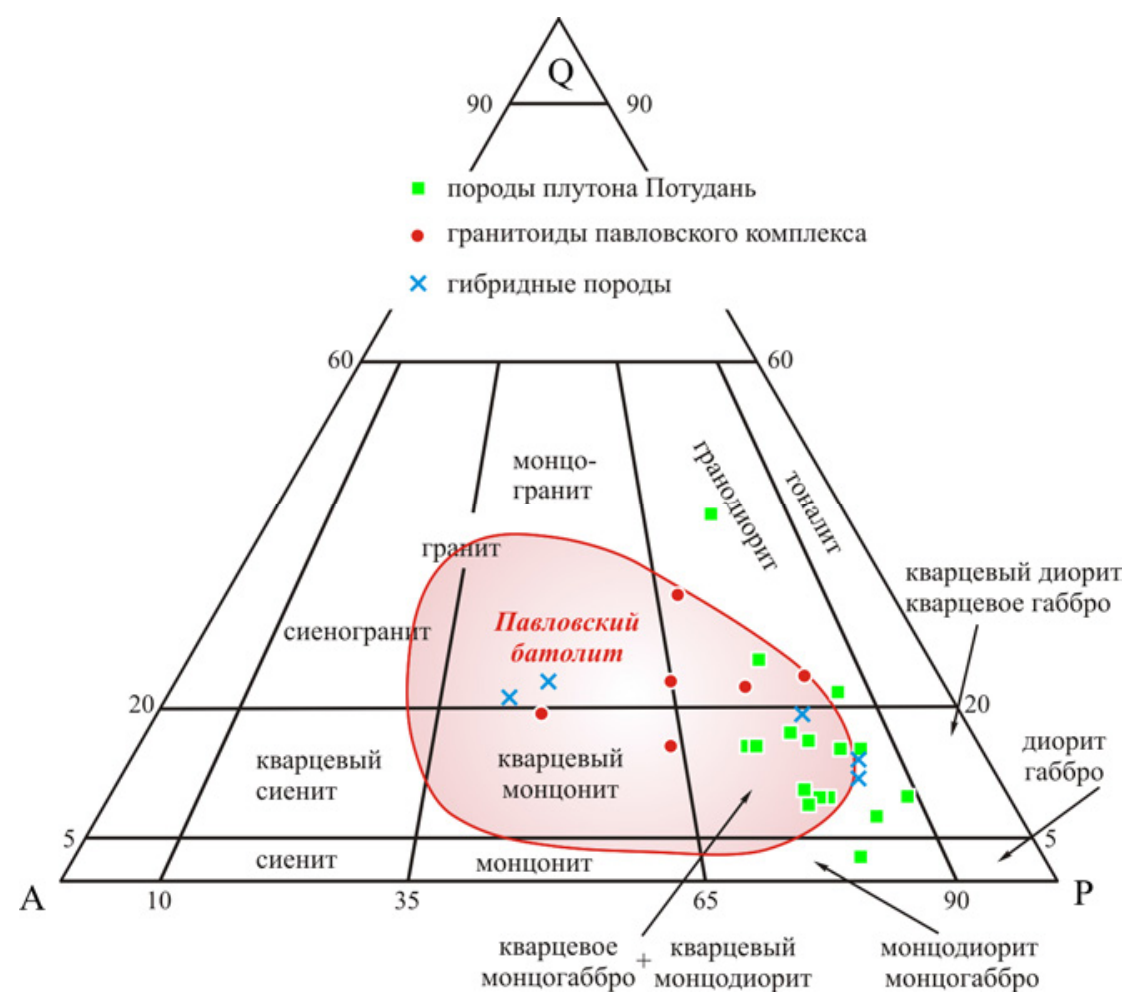

средней зернистостью, массивной текстурой, наличием хорошо сохранившегося клинопироксена или его реликтов, замещенных амфиболом и/или биотитом (чаще наблюдались срастания амфибола и биотита). Значения цветного индекса (М), как правило, не превышают 40\%. По модальному составу и среднему содержанию анортита в плагиоклазе из представительных образцов, породы этой группы классифицируются как кварцевые монцогаббро, кварцевые монцогаббродиориты, кварцевые монцодиориты и гранодиориты (рис. 2). Главные минералы представлены плагиоклазом (32-54 \%), калишпатом (6-22 \%), биотитом (9-22 \%), роговой обманкой $(0,5-12 \%)$, кварцем (5$12 \%)$, клинопироксеном (5-10\%). Акцессорные минералы представлены преимущественно магнетитом (до $6 \%$ ), ильменитом, апатитом, титанитом, цирконом, пирротином, в редких случаях, титаномагнетитом (рис. 3д), халькопиритом.

Полевые unambl. Плагиоклаз представлен тремя генерациями (рис. 4): 1) высококальцевые ядра в зональных кристаллах; 2) ситовидные зональные кристаллы; 3) интерстиции и каймы среднего и кислого состава (An от 0,25-0,49). Интерстиционный плагиоклаз характеризуется изометричными зернами размером 0,4-1,5 мм (рис. 3б). По составу основная масса интерстициальных кристаллов и кайм отвечает олигоклазу $\mathrm{An}_{25-30}$. Зональность проявлена в крупных и средних идиоморфных и гипидиоморфных кристаллах в виде резкого уменьшения анортитового минала от центра к краю (An от 53 до $24 \%$ ) (рис. 3a). В ситовидных плагиоклазах (рис. 3б), включения выполнены преимущественно магнетитом, биотитом, роговой обманкой. В менее серицитизированных зернах отчетливо заметно двойникование. На границе с калишпатом наблюдается мирмекитовая текстура. Содержит включения биотита, калишпатов, апатита, рудных минералов. Калиевый полевой шпат по характерной решетчатой внутренней структуре относится к микроклину. В некоторых крупных кристаллах (размером 1,5-2,5 мм) микроклина отчетливо видны пертитовые вростки плагиоклаза. Более мелкие зерна (до 1,5 мм) микроклина и плагиоклаза слагают интерстиции.

Квари представлен ксеноморфными зернами размером до 1,5 мм, в среднем 0,4 мм и меньше, занимает интерстиции.

Пироксен по своему составу отвечает салиту и авгиту (табл. 1), магнезиальность варьирует слабо

Puc. 2. Модальный минеральный состав пород Потуданского плутона и его окружения на диаграмме QAP [9]: Q - кварц, А - щелочные полевые шпаты, Р - плагиоклаз. 

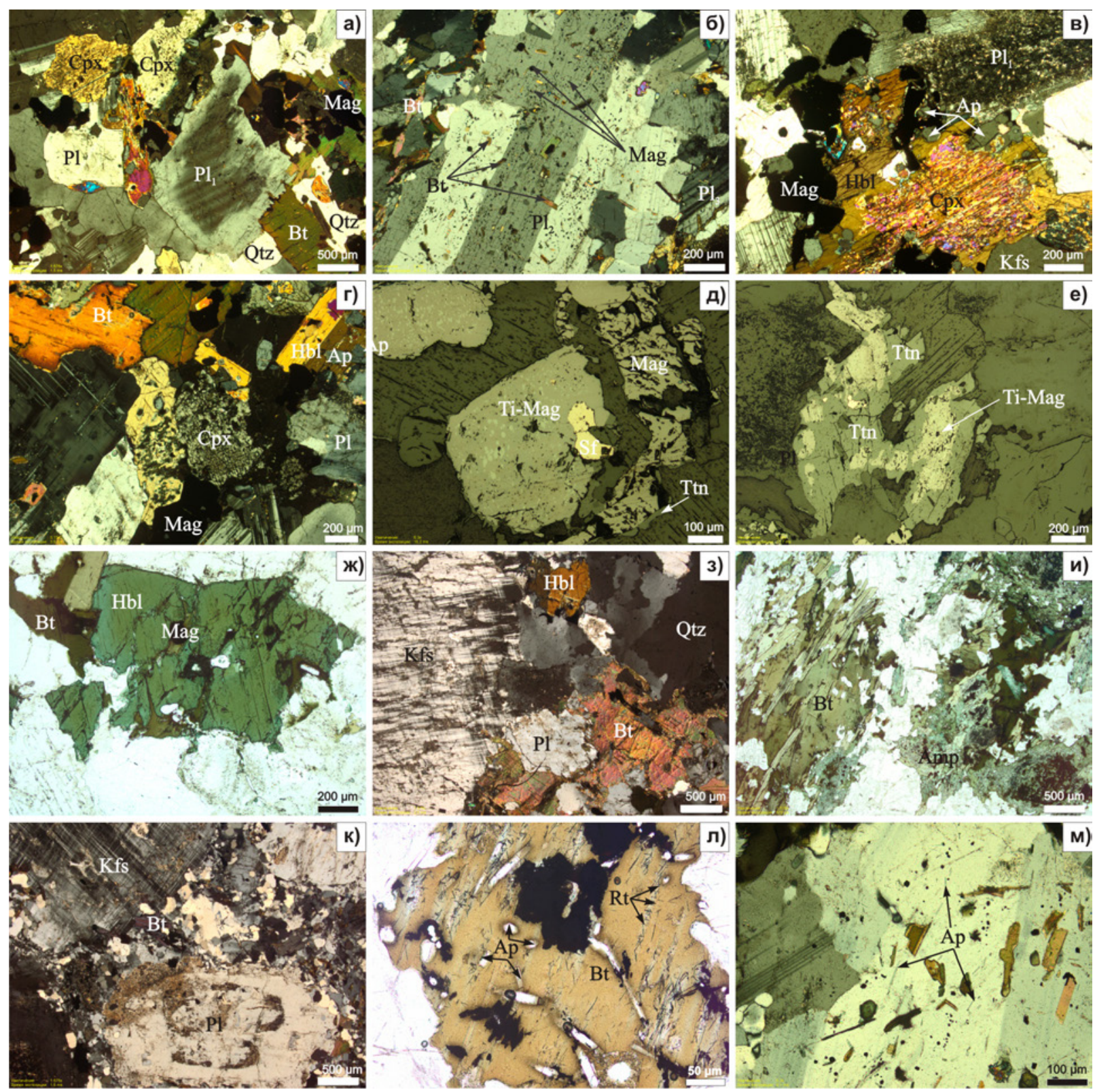

Puс. 3. Фотографии пород под микроскопом: Квариевые монцогаббро-диориты плутона Потудань (а-е): $a$ - зональный плагиоклаз с высококальциевым ядром $\left(\mathrm{Pl}_{1}\right)$, клинопироксен с включениями (роговая обманка, магнетит); $\sigma$ - ситовидный $\left(\mathrm{Pl}_{2}\right)$ и интерстициальный $\left(\mathrm{Pl}_{3}\right)$ плагиоклазы; в - клинопироксен с каймой амфибола, идиоморфный магнетит; 2 - пироксен, амфибол, биотит; $\partial$ - рудные минералы; $e$ - каймы титанита по титаномагнетиту. Гранитоиды павловского комплекса (ж-3). Гибридные породы (и-м): $u$ - шлиры биотита и амфибола; $\kappa$ - фенокристаллы калишпата и плагиоклаза; $л-$ биотит с сагенитовой структурой; $\boldsymbol{M}$ - игольчатый апатит в ситовидном плагиоклазе.

$\mathrm{X}_{(\mathrm{Mg})}=0,65-0,75$, зональных кристаллов не обнаружено. Средний размер зерен составляет 1,3 мм, часто замещен роговой обманкой или же срастаниями роговой обманки с биотитом. Содержит включения магнетита, апатита. Вокруг ядер клинопироксена в некоторых образцах образуется широкая кайма роговой обманки (рис. 3в).

Кальииевый амфибол встречаются как самостоятельные идиоморфные, гипидиоморфные вытянутые призматические так и ксеноморфные кристаллы размером до 2,5 мм, но в большинстве случаев находится в виде кайм вокруг клинопироксена и в срастании с биотитом, замещая пироксен (рис. 3в). Всегда содер- жит включения апатита, ильменита, магнетита, биотита, сульфидов. Более мелкие зерна (до 0,2мм) встречаются вместе с биотитом в виде интерстиций. Большинство амфиболов имеют $(\mathrm{Ca}+\mathrm{Na}) \mathrm{B}>1,5$ и $(\mathrm{Na}+\mathrm{K})_{\mathrm{A}}<0,5$ и относятся к магнезиальным роговым обманкам [10] (рис. 5). Единичные анализы амфиболов соответствуют эденитам. В том случае, когда амфибол замещает пироксен, центр растущего кристалла представлен эденитом, а край выполнен магнезиальной роговой обманкой. Характеризуются умеренной магнезиальностью $\left(\mathrm{X}_{\mathrm{Mg}}=0,56-0,68\right)$ и содержанием глинозема (7,0-8,9 мас. \%). Вторичные амфиболы по химическому составу соответствуют актинолиту. 
An, $\%$

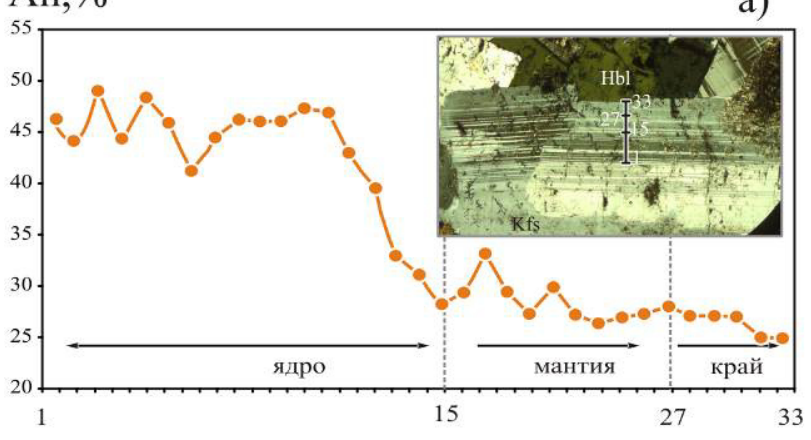

б)

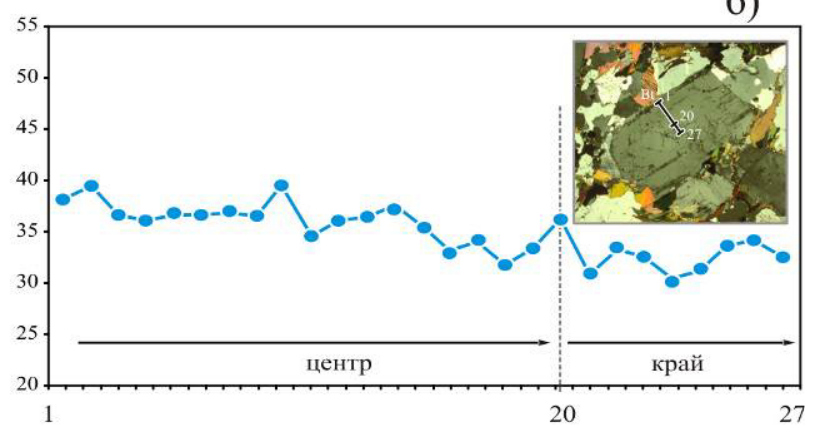

B)

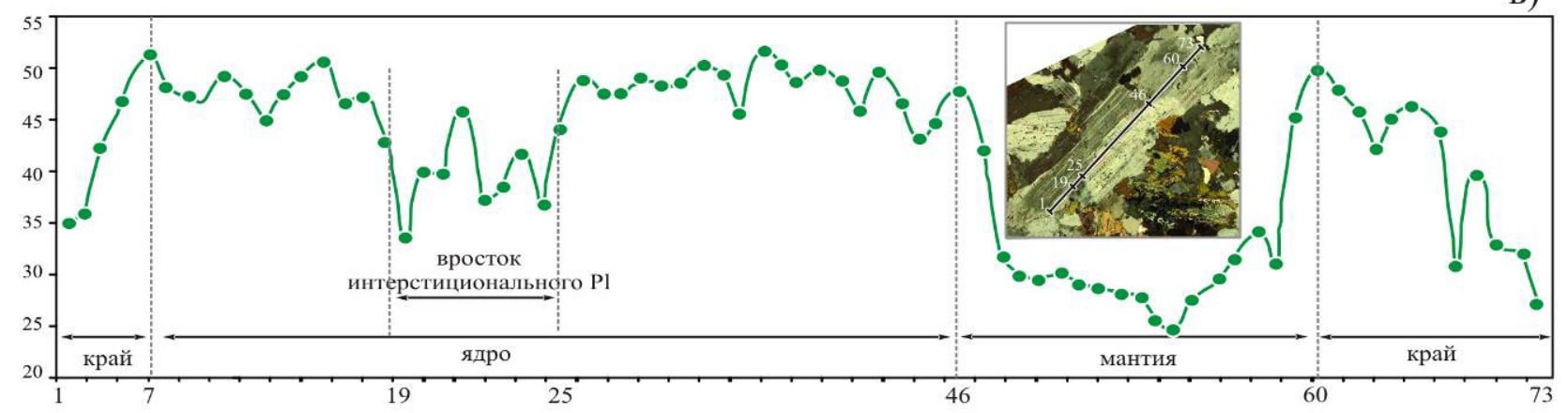

Puc. 4. Зональность кристаллов плагиоклазов по анортитовому миналу: $a$ - типичный зональный плагиоклаз с высококальциевым ядром из габброидов Потуданского плутона; $\sigma$ - слабо зональный плагиоклаз из гранитоидов павловского типа; в - ситовидный плагиоклаз из гибридных пород.

Таблица 1

Представительные микрозондовые анализы клинопироксенов из пород плутона Потудань

\begin{tabular}{|c|c|c|c|c|c|c|c|c|c|c|}
\hline Скважина & 6418 & 6418 & 6418 & 6418 & 6418 & 6418 & 6418 & 8003 & 8003 & 8003 \\
\hline Глубина, м & 62,5 & 62,5 & 66,0 & 66,0 & 66,0 & 66,0 & 66,0 & 400,0 & 400,0 & 400,0 \\
\hline 1 & 2 & 3 & 4 & 5 & 6 & 7 & 8 & 9 & 10 & 11 \\
\hline $\mathrm{SiO}_{2}$ & 52,69 & 53,28 & 52,49 & 52,91 & 52,26 & 53,01 & 52,96 & 52,58 & 51,51 & 52,57 \\
\hline $\mathrm{TiO}_{2}$ & 0,38 & 0,16 & 0,27 & н.п.о. & 0,1 & 0,31 & 0,28 & 0,48 & 0,37 & н.п.о. \\
\hline $\mathrm{Al}_{2} \mathrm{O}_{3}$ & 0,82 & 0,73 & 1,38 & 1,0 & 0,94 & 1,38 & 0,84 & 0,76 & 2,1 & 0,72 \\
\hline $\mathrm{Cr}_{2} \mathrm{O}_{3}$ & 0,06 & н.п.о. & н.п.о. & 0,06 & 0,1 & н.п.о. & н.п.о. & 0,21 & н.п.о. & н.п.о. \\
\hline $\mathrm{FeO}$ & 10,91 & 9,74 & 8,95 & 9,74 & 10,21 & 10,66 & 10,11 & 9,61 & 10,6 & 8,62 \\
\hline $\mathrm{MnO}$ & 0,5 & 0,68 & 0,53 & 0,44 & 0,43 & 0,51 & 0,66 & 0,55 & 0,42 & 0,42 \\
\hline $\mathrm{MgO}$ & 12,08 & 13,22 & 12,86 & 12,61 & 13,45 & 13,43 & 13,16 & 13,1 & 13,25 & 12,88 \\
\hline $\mathrm{CaO}$ & 22,17 & 23,04 & 22,16 & 22,64 & 21,43 & 20,21 & 22,34 & 21,59 & 19,89 & 22,08 \\
\hline $\mathrm{Na}_{2} \mathrm{O}$ & 0,26 & 0,48 & 0,69 & 0,77 & 0,71 & 0,79 & 0,77 & 0,45 & 0,55 & 0,58 \\
\hline $\mathrm{K}_{2} \mathrm{O}$ & н.п.о. & 0,04 & 0,11 & н.п.о. & 0,03 & 0,1 & н.п.о. & н.п.о. & н.п.о. & н.п.о. \\
\hline $\mathrm{Si}$ & 1,99 & 1,97 & 1,97 & 1,97 & 1,96 & 1,97 & 1,96 & 1,98 & 1,95 & 2,00 \\
\hline $\mathrm{Ti}$ & 0,01 & 0,00 & 0,01 & 0,00 & 0,00 & 0,01 & 0,01 & 0,01 & 0,01 & 0,00 \\
\hline $\mathrm{Al}$ & 0,04 & 0,03 & 0,06 & 0,04 & 0,04 & 0,06 & 0,04 & 0,03 & 0,09 & 0,03 \\
\hline $\mathrm{AlVI}$ & 0,03 & 0,00 & 0,03 & 0,02 & 0,00 & 0,03 & 0,00 & 0,02 & 0,05 & 0,00 \\
\hline $\mathrm{Cr}$ & 0,00 & 0,00 & 0,00 & 0,00 & 0,00 & 0,00 & 0,00 & 0,01 & 0,00 & 0,00 \\
\hline $\mathrm{Fe} " '$ & 0,00 & 0,06 & 0,04 & 0,06 & 0,09 & 0,04 & 0,09 & 0,00 & 0,02 & 0,00 \\
\hline $\mathrm{Fe} "$ & 0,34 & 0,24 & 0,24 & 0,24 & 0,23 & 0,29 & 0,23 & 0,30 & 0,31 & 0,27 \\
\hline
\end{tabular}


Продолжение табл. 1

\begin{tabular}{|c|c|c|c|c|c|c|c|c|c|c|}
\hline 1 & 2 & 3 & 4 & 5 & 6 & 7 & 8 & 9 & 10 & 11 \\
\hline $\mathrm{Mn}$ & 0,02 & 0,02 & 0,02 & 0,01 & 0,01 & 0,02 & 0,02 & 0,02 & 0,01 & 0,01 \\
\hline $\mathrm{Mg}$ & 0,68 & 0,73 & 0,72 & 0,70 & 0,75 & 0,74 & 0,72 & 0,74 & 0,75 & 0,73 \\
\hline $\mathrm{Ca}$ & 0,90 & 0,91 & 0,89 & 0,91 & 0,86 & 0,81 & 0,88 & 0,87 & 0,81 & 0,90 \\
\hline $\mathrm{Na}$ & 0,02 & 0,03 & 0,05 & 0,06 & 0,05 & 0,06 & 0,06 & 0,03 & 0,04 & 0,04 \\
\hline $\mathrm{K}$ & 0,00 & 0,00 & 0,01 & 0,00 & 0,00 & 0,00 & 0,00 & 0,00 & 0,00 & 0,00 \\
\hline $\mathrm{X}(\mathrm{Mg})$ & 0,65 & 0,74 & 0,74 & 0,73 & 0,75 & 0,71 & 0,75 & 0,70 & 0,70 & 0,72 \\
\hline $\mathrm{Wol}$ & 46,70 & 47,00 & 47,13 & 47,39 & 44,56 & 42,82 & 46,04 & 45,64 & 42,70 & 47,27 \\
\hline $\mathrm{En}$ & 35,39 & 37,51 & 38,04 & 36,71 & 38,90 & 39,58 & 37,72 & 38,52 & 39,56 & 38,35 \\
\hline $\mathrm{Fs}$ & 17,91 & 15,49 & 14,84 & 15,89 & 16,55 & 17,61 & 16,24 & 15,84 & 17,74 & 14,38 \\
\hline $\mathrm{T}\left(\mathrm{C}^{\circ}\right)$ & 1076 & 1047 & 1102 & 1090 & 1065 & 1113 & 1048 & 1110 & 1154 & 1137 \\
\hline
\end{tabular}

Примечание: н.п.о. - ниже предела обнаружения; $\mathrm{T}^{\circ} \mathrm{C}$ - температуры кристаллизации пород, рассчитаные по данным геотермобарометра клинопироксен-расплав [16].

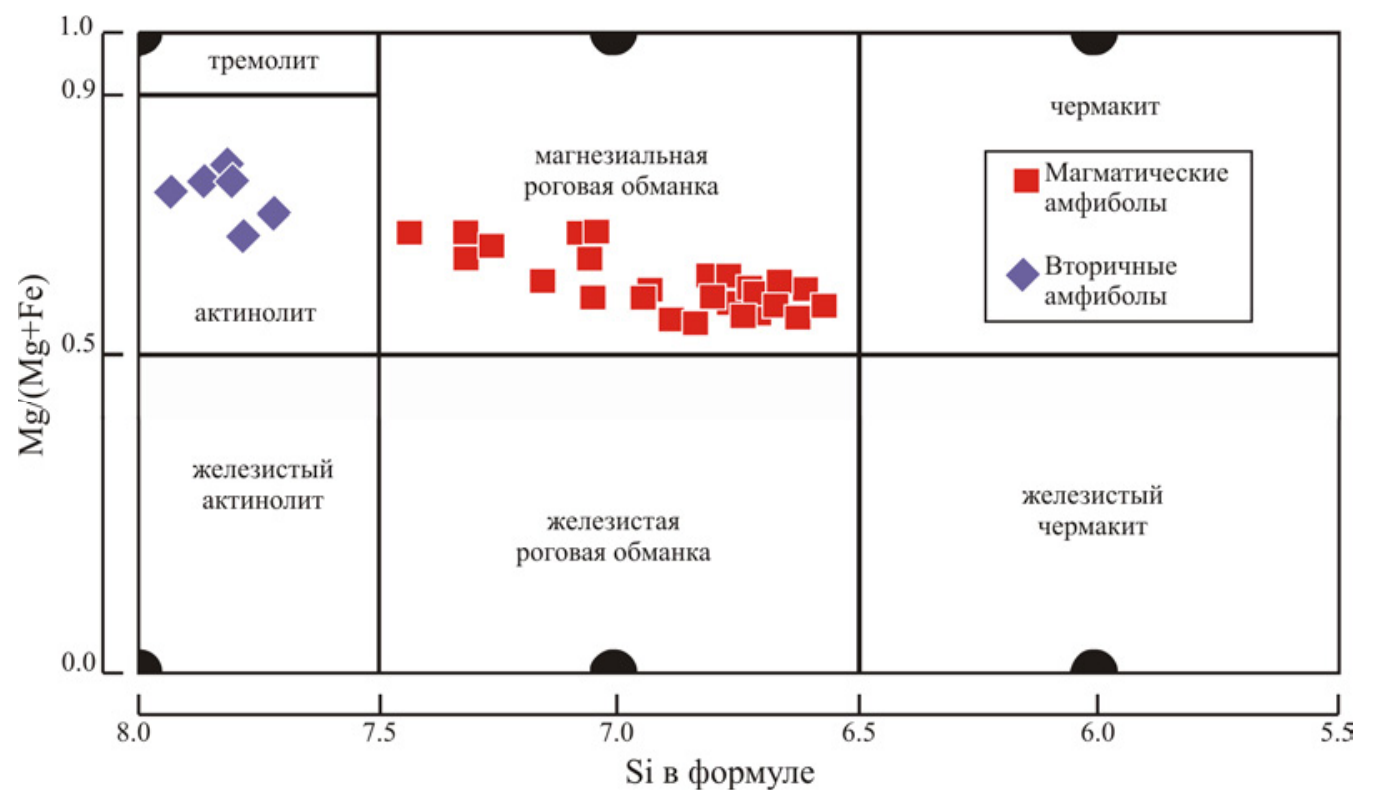

Puc. 5. Составы амфиболов из кварцевых монцодиоритов и кварцевых монцогаббро Потуданского плутона на классификационной диаграмме по [10].

Биотит как правило гипидиоморфен, образует прямоугольные вытянутые чешуи, размером 0,3-0,5 мм. Наблюдаются срастания с роговой обманкой, часто хлоритизирован. Также встречается в виде включений в плагиоклазе (размер зерен менее 0,1 мм). Характеризуется умеренной магнезиальностью $\left(\mathrm{X}_{\mathrm{Mg}}=\right.$ $0,47-0,55)$

Титанит наблюдается в виде двух генераций: 1) самостоятельные идиоморфные клиновидные, конвертообразные кристаллы и 2) ксеноморфные зерна, размером до 0,2-0,8 мм, и каймы вокруг титаномагнетита или магнетита.

Anamum представлен в виде укороченных призм размером до 0,012 мм и шестигранников размером 0,05-0,08 мм. В некоторых образцах из скв. 6416 наблюдаются тончайшие иглы апатита, пронизывающие кристаллы плагиоклаза и калишпата.

Oкcuдbl представлены в преобладающей части идиоморфными магнетитом, ильменитом, ксеноморфным титаномагнетитом.

Сульфидные минераль: идиоморфные пирит и пирротин.

Гранитоиды павловского комплекса.

Преобладающие разновидности павловского типа крупнозернистые, порфировидные (порфировидные кристаллы представлены калишпатом). Встречаются также средне- или мелкозернистые равномернозернистые гнейсовидные гранитоиды с ксенолитами амфиболитов и гнейсов. По модальному составу относятся к кварцевым монцодиоритам, кварцевым монцонитам, монцогранитам и гранодиоритам, реже к монцодиоритам, монцонитам, кварцевым сиенитам и сиеногранитам [3]. Главные минералы представлены плагиоклазом, калишпатом, кварцем, амфиболом, биотитом. Акцессорные минералы: магнетит, титанит, апатит, циркон, эпидот, ильменит. Плагиоклаз более кислый 
по сравнению с кварцевыми монцогаббро-диоритами плутона Потудань, его состав соответствует олигоклазу (в среднем, $\mathrm{An}=20$ ), гипидиоморфный, зональность нормального типа с слабо заметным снижением кальциевости от центра к краю кристаллов. Микроклин отчетливо пертитовый, содержит включения преобладающего плагиоклаза. В редких случаях вокруг фенокристаллов калишпата образуется олигоклазовая кайма, что придает породам структуру рапакиви [3]. Амфибол проявлен как ксеноморфные, гипидиоморфные до идиоморфных зерна, всегда содержащий включения магнетита, плагиоклаза, апатита, титанита. По составу относятся к эденитам и магнезиогастингситам, единичные анализы соответствуют магнезиальной роговой обманке, характеризуется умеренной магнезиальностью $\left(\mathrm{X}_{\mathrm{Mg}}=0,49-0,67\right)$ и умеренными содержаниями глинозема $\left(\mathrm{Al}_{2} \mathrm{O}_{3} 7,8-9,0\right.$ мас. \%). Титанит представлен теми же генерациями, что и в предыдущем типе гранитоидов.

\section{Гибридные породы.}

Эта группа пород сложена теми же породообразующими минералами, что и первые две группы и объединяет в себе особенности как габброидов плутона Потудань, так и гранитоидов павловского комплекса. Признаки, по которым выделены гибридные породы это заметная ориентировка темноцветных минералов и наличие порфировидных вкрапленников, мелкозернистая, часто разнозернистая структура основной массы. Фенокристаллы выполненны калишпатом и плагиоклазом в гетерозернистой основной массе породы. По составу они отвечают кварцевым монцодиоритам, а один образец с обилием мегапорфировых вкрапленников калишпата (до 5 см) попадает в поле монцогранитов. Гибридные породы состоят из пла- гиоклаза (32-45 \%), микроклина (7-20\%), кварца (10$37 \%)$, биотита (7-17\%), роговой обманки (0-11\%), клинопироксена (0-11 \%), акцессорных минералов $(0,2-4 \%)$. Наибольшим идиоморфизмом обладают акцессорные минералы: магнетит, ильменит, циркон, сульфиды; и порфировые вкрапленники плагиоклаза и микроклина. Плагиоклаз соответствует андезину, является контрастно зональным, широко проявлена ситовидная структура. Преобладающая форма апатита игольчатая. Роговая обманка слагает либо шлировидные агрегаты, либо проявлена как результат замещения клинопироксена в виде ксеноморфных кайм и новообразований в центре кристаллов. Для клинопироксена также характерна ситовидная структура; включениями являются магнетит, ильменит, титаномагнетит. Биотит в некоторых образцах демонстрирует сагенитовую структуру, трещины спайности в которой выполнены тончайшими кристаллами рутила (рис. 3л). Часто биотит образует шлировидные скопления (рис. 3и).

\section{Петрохимия}

На диаграммы вынесены составы главных элементов, пересчитанные на безводный остаток и приведенные к сумме 100\%. Представительные химические анализы пород приведены в таблице 2 .

Квариевые монцогаббро-диориты плутона Потудань.

По петрохимическому составу породы плутона Потудань являются основными и средними $\left(\mathrm{SiO}_{2}\right.$ 49,1-63,9 мас. \%). Согласно нормативной классификации Штрекайзена, породы плутона попадают в поля кварцевых монцодиоритов и кварцевых монцонитов. Некоторые образцы (с $\mathrm{SiO}_{2} 60,1-64,3$ мас. \%) попадают в поле гранодиоритов (рис. 6а).
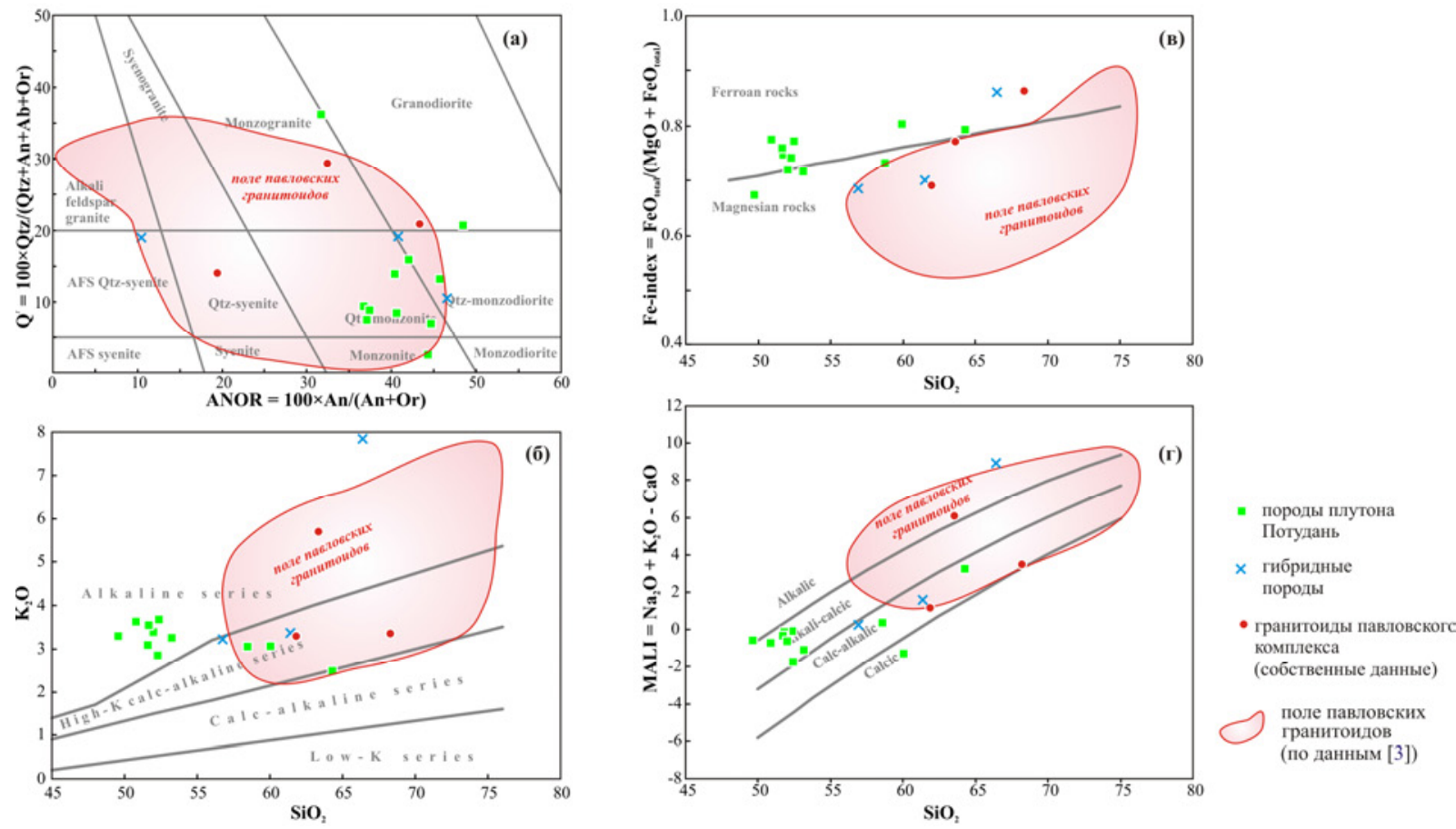

Puc. 6. Составы образцов на классификационных диаграммах: $a$ - по [9]; $\sigma$ - по [11]; 6 , 2 - по [12] 
Химические составы (мас.\%) и концентрации некоторых редких и рассеянных элементов (ррт)пород Хохольско-Репьевского композитного батолита

\begin{tabular}{|c|c|c|c|c|c|c|c|c|c|c|c|c|c|c|c|c|c|}
\hline \multirow[b]{2}{*}{$\begin{array}{c}\text { Порода } \\
\text { Скв./ } \\
\text { глуб. } \\
\end{array}$} & \multicolumn{11}{|c|}{ Потуданский плутон } & \multicolumn{3}{|c|}{ Павловский комплекс } & \multicolumn{3}{|c|}{ гибридные породы } \\
\hline & $\begin{array}{c}\text { Qtz } \\
\text { MGb } \\
8003 / \\
255.0 \\
\end{array}$ & $\begin{array}{c}\text { Qtz } \\
\text { MGb } \\
6418 / \\
66.0 \\
\end{array}$ & $\begin{array}{c}\text { Qtz } \\
\text { MGb } \\
6438 / \\
73.5 \\
\end{array}$ & $\begin{array}{c}\text { Qtz } \\
\text { MGb } \\
6416 / \\
62.0 \\
\end{array}$ & $\begin{array}{c}\text { Qtz } \\
\text { MGb } \\
6425 / \\
73.0 \\
\end{array}$ & $\begin{array}{c}\text { Qtz } \\
\text { MGD } \\
8003 / \\
145.0 \\
\end{array}$ & $\begin{array}{c}\text { Qtz } \\
\text { MGD } \\
8003 / \\
330.0 \\
\end{array}$ & $\begin{array}{c}\text { Qtz } \\
\text { MGD } \\
8003 / \\
400.0 \\
\end{array}$ & $\begin{array}{c}\text { Qtz MDi } \\
8003 / \\
365.0 \\
\end{array}$ & $\begin{array}{c}\mathrm{mGd} \\
6427 / \\
73.5 \\
\end{array}$ & $\begin{array}{c}\mathrm{Gd} \\
8003 / \\
190.0 \\
\end{array}$ & $\begin{array}{c}\text { Qtz Mz } \\
6423 / \\
100.0 \\
\end{array}$ & $\begin{array}{c}\mathrm{Gd} \\
6420 / \\
64.0 \\
\end{array}$ & $\begin{array}{c}\mathrm{Gd} \\
6432 / \\
86.7 \\
\end{array}$ & $\begin{array}{c}\text { Qtz MDi } \\
6434 / \\
102.0 \\
\end{array}$ & $\begin{array}{c}\text { Qtz MDi } \\
8003 / \\
295.0 \\
\end{array}$ & $\begin{array}{c}\mathrm{MGr} \\
6424 / \\
67.0 \\
\end{array}$ \\
\hline $\mathrm{SiO}_{2}$ & 49,05 & 50,26 & 50,58 & 50,91 & 51,63 & 51,80 & 51,94 & 52,91 & 58,01 & 59,53 & 63,95 & 61,23 & 62,80 & 67,89 & 56,21 & 60,95 & 65,46 \\
\hline $\mathrm{TiO}_{2}$ & 2,01 & 2,28 & 1,69 & 1,61 & 2,10 & 2,17 & 1,83 & 2,21 & 1,26 & 2,16 & 0,45 & 0,73 & 0,79 & 0,34 & 0,73 & 0,92 & 0,70 \\
\hline $\mathrm{Al}_{2} \mathrm{O}_{3}$ & 14,09 & 13,71 & 14,60 & 13,68 & 14,12 & 13,88 & 13,40 & 13,22 & 14,34 & 9,83 & 15,77 & 14,68 & 15,53 & 13,56 & 15,52 & 14,68 & 14,68 \\
\hline $\mathrm{Fe}_{2} \mathrm{O}_{3}$ & 13,89 & 13,49 & 12,52 & 13,29 & 11,93 & 12,76 & 12,82 & 11,91 & 8,72 & 12,09 & 6,25 & 7,14 & 5,04 & 5,71 & 8,95 & 7,11 & 4,79 \\
\hline $\mathrm{MnO}$ & 0,136 & 0,132 & 0,122 & 0,176 & 0,108 & 0,140 & 0,107 & 0,118 & 0,080 & 0,117 & 0,085 & 0,093 & 0,048 & 0,067 & 0,124 & 0,095 & 0,037 \\
\hline $\mathrm{MgO}$ & 6,11 & 3,49 & 3,77 & 3,81 & 4,15 & 3,36 & 4,03 & 4,26 & 2,89 & 2,64 & 1,45 & 2,86 & 1,37 & 0,81 & 3,71 & 2,76 & 0,72 \\
\hline $\mathrm{CaO}$ & 6,64 & 7,36 & 6,84 & 6,83 & 7,09 & 6,85 & 7,56 & 7,18 & 6,35 & 6,38 & 3,97 & 5,43 & 3,46 & 3,70 & 6,55 & 5,44 & 1,57 \\
\hline $\mathrm{Na}_{2} \mathrm{O}$ & 2,87 & 3,04 & 3,44 & 3,12 & 3,14 & 3,14 & 3,03 & 2,80 & 3,70 & 2,05 & 4,70 & 3,32 & 3,81 & 3,84 & 3,55 & 3,53 & 2,63 \\
\hline $\mathrm{K}_{2} \mathrm{O}$ & 3,27 & 3,60 & 3,07 & 3,51 & 3,41 & 3,65 & 2,83 & 3,30 & 3,03 & 3,03 & 2,51 & 3,28 & 5,68 & 3,33 & 3,19 & 3,37 & 7,74 \\
\hline $\mathrm{P}_{2} \mathrm{O}_{5}$ & 0,84 & 1,42 & 1,22 & 1,32 & 1,49 & 1,22 & 1,63 & 1,50 & 0,70 & 1,20 & 0,26 & 0,34 & 0,43 & 0,22 & 0,29 & 0,33 & 0,24 \\
\hline $\mathrm{S}$ & 0,083 & 0,114 & 0,187 & 0,263 & 0,185 & 0,097 & 0,155 & 0,108 & 0,163 & 0,109 & $\mathrm{H}, \Pi, \mathrm{O}$, & 0,021 & 0,086 & 0,015 & 0,136 & 0,054 & 0,038 \\
\hline ППІП & 0,48 & 0,67 & 1,33 & 0,73 & 0,22 & 0,37 & 0,26 & 0,24 & 0,25 & 0,48 & 0,37 & 0,57 & 0,29 & 0,41 & 0,70 & 0,42 & 0,83 \\
\hline Сумма & 99,46 & 99,55 & 99,37 & 99,23 & 99,55 & 99,42 & 99,59 & 99,74 & 99,48 & 99,62 & 99,76 & 99,68 & 99,33 & 99,90 & 99,66 & 99,66 & 99,44 \\
\hline $\mathrm{V}$ & 158 & 98,1 & 140 & 140 & 153 & 138 & 172 & 163 & 108 & 136 & 54,8 & 103 & 59,0 & 54,0 & 116 & 96,6 & 47,0 \\
\hline $\mathrm{Cr}$ & 177 & 36,1 & 98,6 & 101 & 53,7 & 29,7 & 84,0 & 67,3 & 44,0 & 98,2 & 42,0 & 93,0 & 29,0 & 44,0 & 93,7 & 89,6 & 43,0 \\
\hline Co & 22,2 & 2,84 & 9,43 & 9,41 & 7,65 & 8,53 & 7,00 & 12,3 & 6,00 & 8,79 & & 8,00 & & & 14,9 & 11,5 & \\
\hline $\mathrm{Ni}$ & 60,7 & 22,9 & 30,8 & 44,8 & 37,3 & 24,2 & 35,0 & 48,3 & 27,0 & 56,2 & 15,8 & 23,0 & 5,00 & 8,00 & 18,7 & 34,0 & 10,0 \\
\hline $\mathrm{Cu}$ & 42,4 & 21,4 & 27,0 & 47,4 & 28,8 & 20,7 & 26,0 & 39,8 & 20,0 & 26,2 & 4,17 & 6,00 & 6,00 & 1,00 & 28,0 & 9,99 & 8,00 \\
\hline $\mathrm{Zn}$ & 112 & 80,7 & 124 & 122 & 131 & 141 & 89,0 & 185 & 76,0 & 128 & 85,0 & 55,0 & 59,0 & 59,0 & 73,0 & 73,0 & 34,0 \\
\hline $\mathrm{Ga}$ & 19,8 & 22,7 & 21,3 & 20,1 & 20,8 & 21,5 & 13,0 & 20,8 & 17,0 & 22,8 & 20,6 & 15,0 & 17,0 & 16,0 & 18,3 & 17,8 & 15,0 \\
\hline $\mathrm{Rb}$ & 81,7 & 79,2 & 87,8 & 88,0 & 84,0 & 91,3 & 44,0 & 83,7 & 53,0 & 89,5 & 64,1 & 97,0 & 98,0 & 62,0 & 108 & 115 & 126 \\
\hline $\mathrm{Sr}$ & 800 & 866 & 790 & 886 & 898 & 879 & 554 & 893 & 755 & 807 & 361 & 442 & 478 & 288 & 551 & 580 & 325 \\
\hline $\mathrm{Y}$ & 27,1 & 27,3 & 32,7 & 32,7 & 31,9 & 35,8 & 17,0 & 31,5 & 16,0 & 32,3 & 21,8 & 7,00 & 16,0 & 16,0 & 18,1 & 9,85 & 15,0 \\
\hline $\mathrm{Zr}$ & 56,3 & 530 & 176 & 280 & 286 & 357 & 52,0 & 373 & 93,0 & 181 & 208 & 121 & 301 & 151 & 162 & 186 & 296 \\
\hline $\mathrm{Nb}$ & 27,4 & 32,5 & 28,7 & 27,6 & 27,4 & 33,2 & 13,0 & 29,7 & 14,0 & 29,3 & 10,8 & 6,00 & 22,0 & 8,00 & 11,2 & 9,52 & 19,0 \\
\hline $\mathrm{Cs}$ & 16,7 & 14,2 & 13,6 & 14,5 & 17,2 & 17,2 & 16,0 & 17,1 & 11,0 & 12,6 & 3,16 & 6,00 & 6,00 & 3,00 & 6,53 & 6,86 & 4,00 \\
\hline $\mathrm{Ba}$ & 2434 & 2300 & 2103 & 2227 & 2542 & 2579 & 2518 & 2743 & 1765 & 2013 & 606 & 1037 & 1226 & 499 & 1006 & 1100 & 915 \\
\hline
\end{tabular}

స Примечания: Qtz MGb - кварцевое монцогаббро, Qtz MGD - кварцевый монцогаббродиорит, Qtz MDi - кварцевый монцоднорит, Qtz Mz - кварцевый монцонит, mGd - мелагранодиорит, Gd - гранодиорит, MGr - монцогранит. 
По составу и соотношению главных элементов габброиды плутона Потудань являются железистыми, известково-щелочными с высокими содержаниями калия (рис. 6а-г), метаглиноземистыми [A/CNK $\left.\left(\mathrm{Al}_{2} \mathrm{O}_{3} / \mathrm{CaO}+\mathrm{Na}_{2} \mathrm{O}+\mathrm{K}_{2} \mathrm{O}\right)<1\right]$ породами. Следует отметить, что образцы с более высоким содержанием кремнезема попадают в поле магнезиальных пород (рис. 6в), являются высококалиевыми и известково-
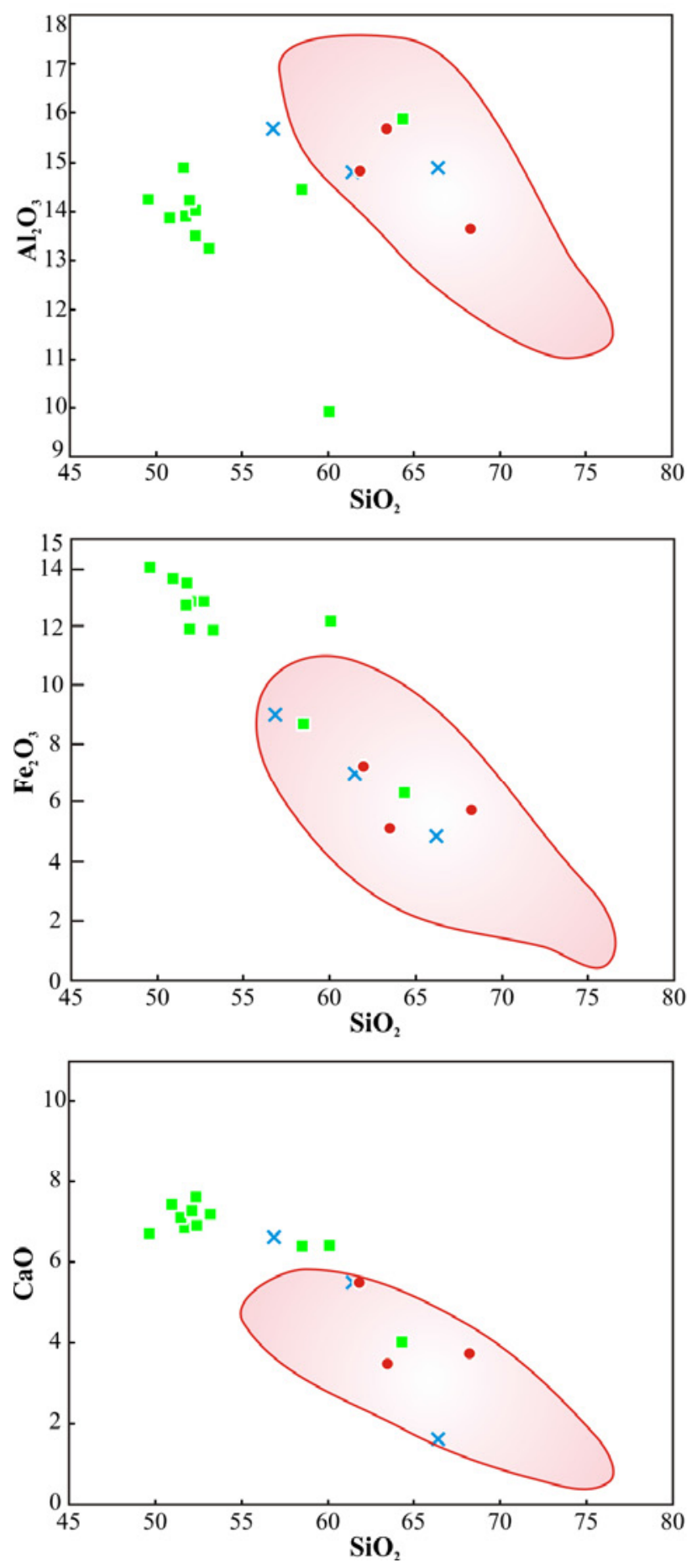

щелочными (рис. 6б,г). На диаграммах Харкера (рис. 7) демонстрируется закономерное уменьшение $\mathrm{Fe}_{2} \mathrm{O}_{3} \mathrm{t}, \mathrm{CaO}, \mathrm{K}_{2} \mathrm{O}$ и увеличение $\mathrm{Na}_{2} \mathrm{O}$ с увеличением $\mathrm{SiO}_{2}$

Все образцы плутона Потудань имеют умеренные до высоких содержания Sr (361-898 ppm), Ва (6062743 ppm), повышенные содержания V (57-172 ppm), $\mathrm{Ni}(16-61 \mathrm{ppm})$ и $\mathrm{Cr}(30-177 \mathrm{ppm})$.
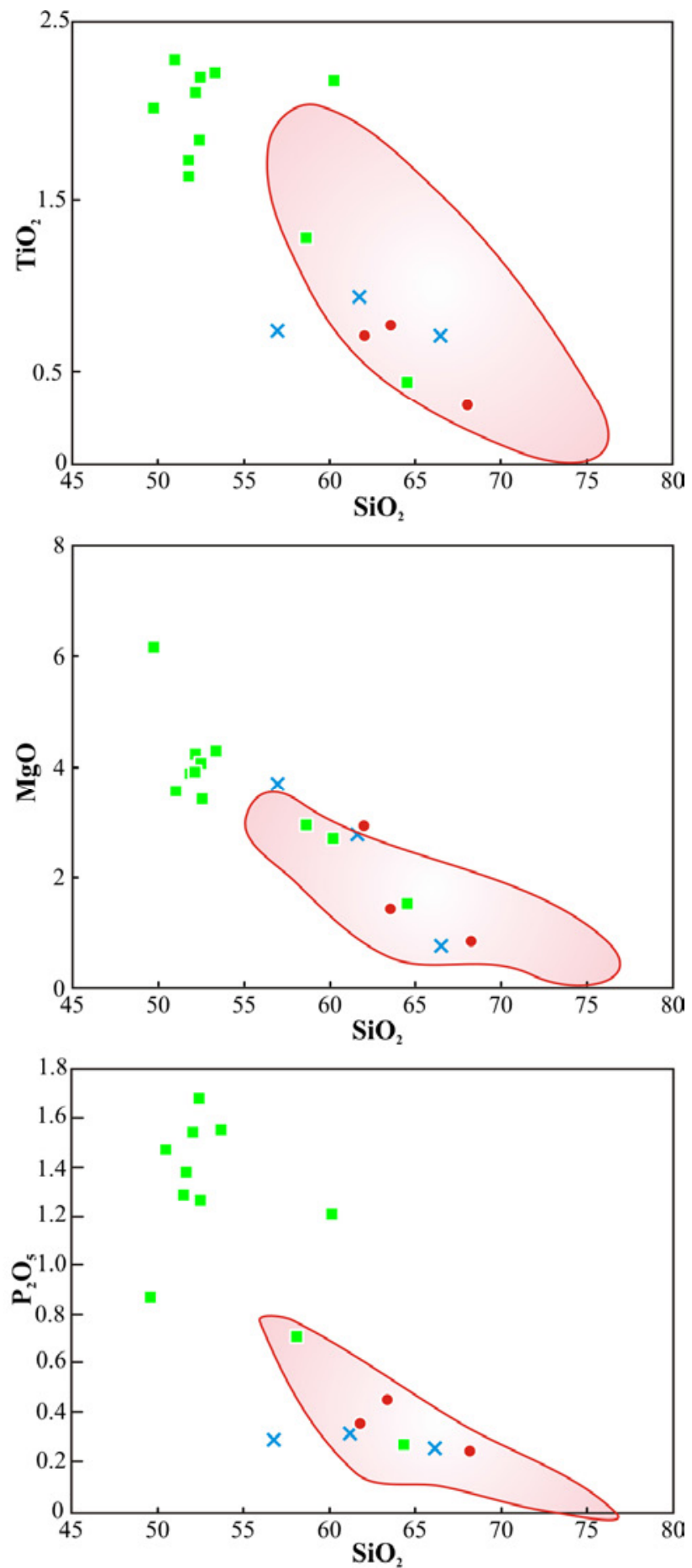

Рис. 7. Главные элементы пород плутона Потудань в сравнении с гранитоидами Павловского батолита. Условные обозначения те же, что на рис. 6. 
Гранитоиды павловского комплекса

Все образцы павловского комплекса характеризуются широкими вариациями содержаний кремнезема от 56,8 до 75,7 мас. \% [3 и наши данные]. Основные представители гранитоидов Павловского типа попадают в поля между кварцевыми монцодиоритами и сиеногранитами, включая кварцевые монцониты, кварцевые сиениты и монцограниты (рис. 6, поле Павловских гранитоидов). Являются магнезиальными и высокомагнезиальными, высококалиевыми, известковощелочными до щелочных (Рис. 6а-г, поле павловских гранитоидов), метаглиноземистыми [A/CNK $\left(\mathrm{Al}_{2} \mathrm{O}_{3}\right.$ / $\left.\mathrm{CaO}+\mathrm{Na}_{2} \mathrm{O}+\mathrm{K}_{2} \mathrm{O}\right)<1$ ] породами [3 и наши данные].

$\mathrm{B}$ отличие от потуданских монцогаббро-диоритов павловские гранитоиды Хохольско-Репьевского батолита демонстрируют меньшие содержания $\mathrm{Sr}$ (288-478 ppm) и Ва (499-1226 ppm), характеризуются умеренными содержаниями V (54-103 ppm) и Ni (5-23 ppm).

\section{Гибридные породы}

Этот тип пород по соотношению кварцполевошпатовой части достаточно сильно варьирует, относясь и к гранодиоритам, и к кварцевым сиенитам (рис. 6а) за счет порфировых и мегапорфировых вкрапленников калишпата в некоторых образцах. По содержаниям кремнезема являются средними и кислыми породами, характеризуются умеренной магнезиальностью, метаглиноземистостью, являются высококалиевыми и кальцево-щелочными. Однако, образцы, в которых выделены мегапорфиры калишпата, с повышенным содержанием $\mathrm{SiO}_{2}$ являются железистыми и щелочными.

По содержаниям редких и рассеяных элементов гибридные породы занимают промежуточное положение между павловскими гранитоидами и мафитами плутона Потудань: Sr (325-580 ppm), Ва (915-1100 ppm), V (47-116 ppm), Cr (43-94 ppm) и Ni (10-34 ppm).

\section{Обсуждение результатов}

\section{Условия кристаллизации плутона Потудань}

Первоначально оценки температур, литостатического давления были получены при помощи амфиболплагиоклазового геотермометра [13] и Al-в-амфиболе геобарометра [14]. Для расчетов были выбраны кристаллы амфибола близкие к идиоморфным, с минимальным количеством или отсутствием включений и граничащие с плагиоклазом. В мафитовых образцах оценки температур выше или близки (около $800{ }^{\circ} \mathrm{C}$ ) к предельному значению температуры, выше которой геобарометр по [13] не калиброван. Поэтому, давления были пересчитаны с использованием геобарометра по [15], который используется в более широком интервале температур. Наблюдается понижение температуры от центра к краю кристаллов амфибола (от $851^{\circ} \mathrm{C}$ до $713^{\circ} \mathrm{C}$ ) при постоянном давлении $2,7-3,2$ кбар.

Температуры ликвидуса оценены по геотермометру клинопироксен-расплав [16]. Центры кристаллов клинопироксена формируются при температурах $1047-1154^{\circ} \mathrm{C}$, а краевые части при $1076-1114^{\circ} \mathrm{C}$. Температуры кристаллизации, рассчитанные по геотермометру апатитового насыщения [17] составили: для мафитов Потуданского плутона $1000-1100^{\circ} \mathrm{C}$, а для директивных порфировидных мелкозернистых кварцевых монцодиоритов гибридного типа $-815-900^{\circ} \mathrm{C}$. Идиоморфный габитус апатита, включения апатита в породообразующих минералах, уменьшение $\mathrm{P}_{2} \mathrm{O}_{5}$ c увеличением кремнезема, говорит о том, что апатит был ликвидусной фазой, а полученные температуры соответствуют начальной стадии кристаллизации плутона и гибридных пород, соотвественно. Температуры цирконового насыщения [18] значительно ниже, что свидетельствует о том, что циркон формировался позднее апатита и является субликвидусным. Для массивных габброидов плутона Потудань температуры кристаллизации циркона варьируют от 612 до 800 ${ }^{\circ} \mathrm{C}$, для гибридных пород от 730 до $847^{\circ} \mathrm{C}$. Оценки температур по амфибол-плагиоклазовому [13] и титаномагнетитового [19] геотермометрам подтверждают, что субликвидусные температуры Потуданского плутона находятся в пределах $700-800^{\circ} \mathrm{C}$.

По нашим данным, температуры кристаллизации пород павловского комплекса в пределах ХохольскоРепьевского батолита, рассчитанные по амфиболплагиоклазовому и апатитового насыщения геотремометрам (стартовые $838-980^{\circ} \mathrm{C}$ и завершающие 704$731^{\circ} \mathrm{C}$ ) ниже, чем в плутоне Потудань, но близки к температурам магм гибридного типа. Литостатическое давление для большинства пород, слагающих композитный Хохольско-Репьевский батолит, колеблется около среднего значения 3 кбар (табл. 3).

Таблица 3

Параметры кристаллизации пород Хохольско-Репьевского композитного батолита

\begin{tabular}{|c|c|c|c|c|}
\hline $\begin{array}{c}\text { Параметр (геобарометр, } \\
\text { геотермометр) }\end{array}$ & [Ссылка] & $\begin{array}{c}\text { Плутон } \\
\text { Потудань }\end{array}$ & $\begin{array}{c}\text { Гибридные } \\
\text { породы }\end{array}$ & $\begin{array}{c}\text { Павловский } \\
\text { комплекс }\end{array}$ \\
\hline Давление (Al-in-Amp) & {$[15]$} & 2,7-3,2 кбар & - & 3,0-3,5 кбар \\
\hline Давление (Al-in-Amp) & {$[14]$} & 1,7-2,9 кбар & - & 2,3-3,4 кбар \\
\hline Температура (Срх-жидкость) & [16] & $1047-1154{ }^{\circ} \mathrm{C}$ & - & - \\
\hline Температура (Ар насыщения $)$ & [17] & $1000-1100{ }^{\circ} \mathrm{C}$ & $815-900{ }^{\circ} \mathrm{C}$ & $838-980{ }^{\circ} \mathrm{C}$ \\
\hline Температура (Hbl-Pl) & [13] & $713-851^{\circ} \mathrm{C}$ & - & $704-731{ }^{\circ} \mathrm{C}$ \\
\hline Температура (Ti-mag/ilm) & [19] & $702-779^{\circ} \mathrm{C}$ & - & - \\
\hline Температура $\left(\mathrm{Zr}_{\text {насыщения }}\right)$ & {$[18]$} & $612-800{ }^{\circ} \mathrm{C}$ & $730-847^{\circ} \mathrm{C}$ & $701-857^{\circ} \mathrm{C}$ \\
\hline
\end{tabular}




\section{Типизация и вопросы происхождения габброидов плутона Потудань}

Во введении отмечены смежные магматические комплексы, с которыми у мафитов плутона Потудань могли бы наблюдаться генетические связи. Эти местные геологические подразделения представлены белогорьевским горнблендит-габбровым и павловским гранитоидным комплексами. Массивы белогорьевского комплекса предполагаются в районе ХохольскоРепьевского батолита (рис. 1б) по геофизическим данным, отдельные маломощные тела вскрыты единственной скважиной (7770) на севере батолита. Белогорьевский комплекс представлен преобладающими горнблендитами, реликтовыми пироксенитами и редкими габброидами, как правило, метаморфизованными вплоть до образования габбро-амфиболитов [2]. Кроме того, ультрамафит-мафиты Белогорьевского петротипа характеризуются высокой магнезиальностью пород и слагающих их темноцветных минералов, клинопироксенов и амфиболов [Терентьев, неопубликованные данные] по сравнению с мафитами плутона Потудань. Высокие содержания щелочей, особенно калия, железистый химизм (рис. 6) пород также контрастно отличают габброиды плутона Потудань от ультрамафитмафитов белогорьевского комплекса.

С другой стороны, петрографические особенности плутона Потудань, такие как присутствие кварца, калиевого полевого шпата, средний химизм некоторых образцов и микроструктурные особенности сближают его с наиболее меланократовыми породами павловского комплекса. Магнезиальность амфиболов и клинопироксенов мафитов плутона Потудань идентична магнезиальности амфиболов из гранитоидов павловского типа Хохольско-Репьевского батолита и составам ядер клинопироксенов из меланократовых пород петротипического Павловского батолита [3]. Такое сходство пород и минералов, наряду с пространственной сопряженностью гранитоидов павловского комплекса и мафитов плутона Потудань в пределах единого композитного батолита, наводят на мысль о их генетической связи. Возможные, на наш взгляд, варианты такой связи: (1) мафиты плутона Потудань - это кумулаты средних-кислых магм павловского типа; (2) павловские гранитоиды - продвинутые дериваты родоначальных магм Потуданского плутона; и (3) смешение в разных пропорциях близкоодновозрастных магм контрастного состава. Типичных кумулятивных структур и текстур в мафитах плутона Потудань не наблюдается. Для кумулатов, как правило, характерно сильное обогащение совместимыми элементами, например $\mathrm{Mg}, \mathrm{Cr}, \mathrm{V}, \mathrm{Ni}, \mathrm{Co}$, что не свойственно мафитам изученного плутона. Эти признаки позволяют отвергнуть первый вариант генезиса. Дифференциация (версия №2) от мафитов плутона Потудань к гранитоидам павловского типа не реализуемый процесс по следующим причинам: железистый химизм первых и повышенная магнезиальность вторых; противоположные эволюционные тренды обоих типов на бинарных диаграммах (рис. 6 и 7), например, по $\mathrm{K}_{2} \mathrm{O}$ и
$\mathrm{Al}_{2} \mathrm{O}_{3}$. Наиболее правдоподобный вариант №3 (взаимодействие контрастных магм) подтверждается петрографическими и минералогическими особенностями, которые рассмотрены в следующем разделе.

Важный промежуточный вывод - плутон Потудань является продуктом самостоятельного магматического эпизода и позиционируется как новое геологическое подразделение (комплекс) ВКМ.

\section{Смешение гранитоидных и габброидных магм}

Согласно петрографических наблюдений порядок кристаллизации магм плутона Потудань следующий (от ранних к поздним): (1) $\mathrm{Cpx}, \mathrm{Mag}, \mathrm{Ap}, \mathrm{Ttn}_{1}$ и сульфиды; (2) Zrn, Amp, $\mathrm{Pl}_{1}$ и $\mathrm{Ttn}_{2}$; (3) Bt, Qtz, Kfs и $\mathrm{Pl}_{2-3}$. Схожий порядок кристаллизации установлен для гранитоидов павловского комплекса [3]. До некоторого предела близки оценки температур начала кристаллизации и литостатические давления для габброидов плутона Потудань и наиболее меланократовых пород павловского комплекса. Минералого-петрографическое сходство мафитов плутона Потудань и гранитоидов павловского типа, а также близость условий кристаллизации их магм свидетельствуют о потенциальной возможности гибридизации. Единственным препятствием для смешения контрастных расплавов является различие их вязкости $[20,21]$. Средняя расчетная вязкость при сухих и водонасыщенных условиях составляет 2,8 и 3,1 Па.с для мафитов плутона Потудань и 6,8 и 5,5 Па.с для гранитоидов павловского типа. Не смотря на высокую разницу вязкости, высокие стартовые температуры более $1000{ }^{\circ} \mathrm{C}$ обоих типов магм, при условии низкой доли кристаллов в расплаве, нивелируют контрастность физических свойств расплавов [22]. Смешение конрастных магм подтверждается находками гибридных пород, которые наследуют петрографо-минералогические признаки и габброидов плутона Потудань, и вмещающих гранитоидов павловского комплекса. Кроме того, гибридные породы по химическому составу занимают промежуточное положение между составами мафитов и гранитоидов, изученных в данной работе.

Петрографические и минералогические признаки смешения мафитовых и кислых магм на верхнекоровом уровне (до 15 км):

(1) Типичные кристаллы плагиоклаза из мафитов Потуданского плутона характеризуются высококальциевым ядром, окруженным более кислым плагиоклазом. Граница между двумя зонами резкая как внешне под микроскопом, так и по изменению анортитового минала (рис. 4а). Резкое изменение состава плагиоклаза от основного к кислому с последующим переуравновешиванием системы и фракционированием минеральной фазы возможно путем добавления кислого расплава к мафитовому или наоборот [23].

(2) Ситовидные кристаллы плагиоклаза характерны для гибридных пород, спорадически они встречаются в габброидах Потуданского плутона. Их необычная зональность с резким падением кальциевости в мантийной части и таким же резким повышением 
анортитового минала к краю свидетельствуют не только о добавлении кислого расплава в мафитовый, но и о повторной порции мафитовой магмы. В целом, доказано, что ситовидная структура плагиоклаза является следствием переохлаждения гибридной магмы $[24,25]$. Также и в нашем случае, породы, отнесенные к гибридным теряют стартовые температуры кристаллизации более чем на $100{ }^{\circ} \mathrm{C}$ по сравнению с мафитами плутона Потудань (табл. 3).

(3) Кварцевые и/или калишпатовые ойкокристаллы спорадически проявленые в мафитах Потуданского плутона и обильные в гибридных породах. Считается, что такие ойкокристаллы фомируются после смешивания магм [25, 26] при достижении термального равновесия между мафитовым и кислым расплавами [27].

(4) Игольчатый апатит встречается в некоторых образцах габброидов Потуданского плутона, обилен в гибридных породах. Другая генерация апатита из габброидов характеризуется изометричной бочонкообразной формой. Экспериментально показано, что игольчатые кристаллы формируются в условиях переохлаждения и, соотвественно считаются косвенным доказательством смешения мафитовой и относительно холодной кислой магм [28].

(5) Дополнительными аргументами в пользу смешения мы считаем наличие в гибридных породах: шлировидных агрегатов биотита и амфибола, неравномернозернистые структуры основной массы, присутствие «дендровидного» Fe-Ті-оксида, сагенитовая структура биотита.

Так как гибридные породы составляют не более 5\% от керна скважин, вскрывших плутон Потудань, а минералого-петрографические признаки смешения установлены в габброидах плутона спорадически, то смешение с кислыми магмами павловского типа происходило в разных и небольших пропорциях. Другими словами, гибридизация магм не затушевала другие процессы, например дифференциацию, характер и направленность которой различны в габброидной и гранитоидной ветвях композитного ХохольскоРепьевского батолита.

\section{Выводы}

1. Согласно петрографических и петрохимических данных, плутон Потудань выделен как самостоятельное геологическое подразделение ВКМ. Он состоит преимущественно из пироксеновых кварцевых монцогаббро, кварцевых монцогаббродиоритов дифференцированых до кварцевых монцодиоритов и гранодиоритов железистой, известково-щелочной серий. Вмещающие породы представлены ХохольскоРепьевским батолитом роговообманково-биотитовых магнезиальных гранитоидов павловского комплекса.

2. Оценены условия кристаллизации плутона Потудань: давление 2,7-3,2 кбар (глубина внедрения 911 км); температуры начала кристаллизации - 1114$1154^{\circ} \mathrm{C}$, температуры субликвидусной области 700 $800^{\circ} \mathrm{C}$. Полученные параметры (высокие стартовые температуры и литостатическое давление) сопоставимы с таковыми по гранитоидам павловского комплекca.

3. Минералого-петрографические особенности пород плутона Потудань, такие как прямая и реверсивная зональность плагиоклаза с резким изменением состава от ядра к краю, ситовидный плагиоклаз, кварцевые и/или калишпатовые ойкокристаллы, игольчатый апатит и другие признаки гибридизма габброидов плутона и вмещающих гранитоидов свидетельствуют о смешении в разных пропорциях мафитовой и кислой магм в верхнекоровых условиях.

\section{ЛИТЕРАТУРА}

1. Bogdanova, S. V. Segments of the East European Craton / S. V. Bogdanova // In Gee, D. G., and Beckholmen, M., (eds.) EUROPROBE in Jablonna 1991: Polish Academy of Sciences,Publications of the Institute of Geophysics. - 1993. - V. A 20. - P. 33-38.

2. Одокий, A. А. Некоторые данные по докембрию юговосточной части Воронежской области / А. А. Одокий // Тезисы межобластного геологического совещания по геологии и минеральным ресурсам ЦЧО, Воронеж, 1962. - с.103106.

3. Терентьев, P. А. Минеральная термобарометрия и геохимия палеопротерозойских магнезиально-калиевых гранитоидов Павловского плутона, Восточно-Европейский кратон / Р. А. Терентьев, К. А. Савко // Вестн. Воронеж. ун-та. Сер.: Геология. - 2017. - № 3. - С. 34-45.

4. Late Archaean crust-mantle interactions in the Closepet granite, Southern India: evidence from $\mathrm{Sr}-\mathrm{Nd}$ isotopes, major and trace element geochemistry / M. Jayananda [et al.] // Contrib. Mineral. Petrol. - 1995. - V. 119. - P. 314-329.

5. Martin, $H$. The sanukitoid series: magmatism at the Archaean-Proterozoic transition / H. Martin, J. F. Moyen, R. Rapp // Earth and Environmental Science Transactions of the Royal Society of Edinburgh, 2010. - V. 100. - P. 15-33.

6. Египко, О. И. Некоторые минералого-петрографические и геохимические особенности докембрийских гранитоидов юго-восточной части Воронежского кристаллического массива: дисс. ... канд. геол.-минерал. наук / О. И. Египко. Воронеж: Изд-во Воронеж. гос. ун-та. - 1971. - 367 с.

7. Бердников, М. Д. Раннедокембрийский гранитоидный комплекс юго-востока ВКМ / М. Д. Бердников, С. П. Молотков // Вопросы геологии и металлогении докембрия ВКМ. Воронеж, 1977. - С. 14-20.

8. Структурно-тектоническое районирование ВКМ (по геологическим и геофизическим данным) / Н. М. Чернышов [и др.] / Современные проблемы геологии: мат-лы юбилейной научной сессии геолог. ф-та ВГУ. - Воронеж. - 1998. C. 5-7.

9. Le Maitre, $R$. W. Igneous Rocks. A Classification and Glossary of Terms. Recommendations of the International Union of Geological Sciences Subcommission on the Systematics of Igneous Rocks, 2nd ed. / R. W. Le Maitre (ed.) // Cambridge, New York, Melbourne: Cambridge University Press. Geol. Mag. 2002. - V. 140. - 367 p.

10. Nomenclature of amphiboles: report of the Subcommittee on Amphiboles of the International Mineralogical Association, Commission on New Minerals and Mineral names / B. E. Leake [et al.] // The Canadian Mineralogist. - 1997. - V. 35. - P. 219246.

11. Ewart, A. The mineralogy and petrology of Tertiary-Recent orogenic volcanic rocks: with special reference to the andesitic- 
basaltic compositional range / R. S. Thorp, (ed.) //Andesites: Orogenic Andesites and Related Rocks, John Wiley and Sons, New York, 1982. - P. 25-95.

12. A geochemical classification for granitic rocks / B. R. Frost [et al.] // J. Petrol. - 2001. - V. 42. - P. 2033-2048.

13. Holland, $T$. Non-ideal interactions in calcic amphiboles and their bearing on amphibole-plagioclase thermometry / T. Holland, J. Blundy // Contrib. Mineral. Petrol. - 1994. - V. 116. P. 433-447.

14. Anderson, $J$. $L$. The effects of temperature and $\mathrm{fO}_{2}$ on the Al-in-hornblende barometer / J. L. Anderson, D. R. Smith // Am. Mineral. - 1995. - V. 80. - P. 549-559.

15. An experimental study of amfibole stability in low-pressure granitic magmas and a revised Al-in-hornblende geobarometer / E. J. F. Mutch [et al.] // Contrib Mineral Petrol, 2016. - V. 171:85. -27 p.

16. Putirka, K. Thermometers and Barometers for Volcanic Systems / K. Putirka, F. Tepley (eds.) // Minerals, Inclusions and Volcanic Processes, Reviews in Mineralogy and Geochemistry, Mineralogical Soc. Am. - 2008. - V. 69. - P. 61-120

17. Harrison, T. M. The behaviour of apatite during crustal anatexis: equilibrium and kinetic considerations / T. M. Harrison, E.B. Watson // Geochim. Cosmochim. Acta. - 1984. - V. 48. P. 1467-1477.

18. Watson, E. B. Zircon saturation revisited: temperature and composition effects in a variety of crustal magma types / E. B. Watson, T. M. Harrison // Earth Plan. Sci. Lett. - 1983. - V. 64. - P. 295-304.

19. Andersen, D.J. New (and final!) models for the Timagnetite/ilmenite geothermometer and oxygen barometr / D. J. Andersen, D. H. Lindsley // Abstract AGU, Spring Meeting Eos Transactions. American Geophysical Union 66, 1985. - V. 18 $416 \mathrm{p}$.

\section{Воронежский государственный университет}

Петракова Марина Евгеньевна, аспирант кафедры полезных ископаемых и недропользования

E-mail:maribya@mail.ru

Тел.: 8-964-335-58-38

Терентьев Роман Анатольевич, ведущий научный сотрудник НИИ Геологии ВГУ, кандидат геолого-

минералогических наук

E-mail: terentiev@geol.vsu.ru

Тел.: 8 (473) 222-73-63
20. Sparks, S. R. J., Thermal and mechanical constraints on mixing between mafic and silicic magmas / S. R. J. Sparks, L. A. Marshall // J. Volcanol. Geotherm. Res. - 1986. - V. 29. P. 99-124.

21. . Dynamic mixing in magma bodies: theory, simulations and implications / C. M. Oldenburg [et al.] // J. Geophys. Res. 1989. - V. 94. - P. 9215-9236.

22. On the conditions of magma mixing and its bearing on andesite production in the crust / M. Laumonier [et al.] // Nature Communications. - 2014. - V. 5. - 5607 p.

23. Magma-mixing in the genesis of Hercynian calc-alkaline granitoids: an integrated petrographic and geochemical study of the Sázava intrusion, Central Bohemian Pluton, Czech Republic / V. Janoušek [et al.] // Lithos. - 2004. - V. 78. - P. 67-99.

24. Hibbard, M. J. The magma mixing origin of mantled feldspars / M. J. Hibbard // Contrib. Mineral. Petrol. - 1981. - V. 76. - P. $158-170$.

25. Vernon, $R$. H. Crystallization and hybridism in microgranitoid enclave magmas: microstructural evidence / R. H. Vernon // J. Geophys. Res. - 1990. - V. 95. - P. 17849- 17859.

26. Baxter, $S$. Magma mixing and mingling textures in granitoids: examples from the Galway Granite, Connemare, Ireland / S. Baxter, M. Feely // Mineralogy and Petrology. - 2002. - V. 76. - P. 63-74.

27. Castro, A. H. (Hybrid)-type granitoids: a proposed revision of the granite-type classification and nomenclature / A. H. Castro, I. Moreno-Ventas, J. D. De la Rosa // Earth-Sci. Rev. - 1991. - V. 31. - P. 237-253.

28. Hibbard, M. J. Textural anatomy of twelve magma-mixed granitoid systems / In: Didier, J., Barbarin, B. (Eds.), Enclaves and Granite Petrology. Elsevier, Amsterdam, 1991. - P. 431444.

\section{Voronezh State University}

Petrakova M. E., Graduate student of the Mineral Resource Department

E-mail:maribya@mail.ru

Tel.: 8-964-335-58-38

Terentiev R. A., leading researcher of Scientific Research Institute of Geology of the VSU, Candidate of Geological and Mineralogical Sciences

E-mail: terentiev@geol.vsu.ru

Tel.: 8 (473) 222-73-63 